IMAGINING NEW LEGALITIES 
The Amherst Series in Law, Jurisprudence, and Social Thought E D I T E D B Y Austin Sarat, Lawrence Douglas, and Martha Merrill Umphrey 


\title{
Imagining New Legalities
}

Privacy and Its Possibilities in the 21st Century

\author{
Edited by
}

AUSTIN SARAT

LAWRENCE DOUGLAS

MARTHA MERRILL UMPHREY

STANFORD LAW BOOKS

An imprint of Stanford University Press - Stanford, California 
Stanford University Press

Stanford, California

(C) 2012 by the Board of Trustees of the

Leland Stanford Junior University

No part of this book may be reproduced or transmitted in any form or by any means, electronic or mechanical, including photocopying and recording, or in any information storage or retrieval system without the prior written permission of Stanford University Press.

Library of Congress Cataloging-in-Publication Data

Imagining new legalities : privacy and its possibilities in the 21st century / edited by Austin Sarat, Lawrence Douglas, and Martha Merrill Umphrey.

pages $\mathrm{cm}$. - (The Amherst series in law, jurisprudence, and social thought)

Includes bibliographical references and index.

ISBN 978-0-8047-7704-9 (cloth : alk. paper)

1. Privacy, Right of. 2. Privacy, Right of-United States.

I. Sarat, Austin, editor of compilation. II. Douglas, Lawrence, editor of compilation. III. Umphrey, Martha Merrill, editor of compilation. IV. Series: Amherst series in law, jurisprudence, and social thought.

K3263.1525 2012

$342.08^{\prime} 58-\mathrm{dc} 23$

2011036760

Printed in the United States of America on acid-free, archivalquality paper

Typeset at Stanford University Press in 10/14.5 Minion 
To Ben (AS) 
